\title{
Variations in the oxygen isotopic composition of precipitation in the Tianshan Mountains region and their significance for the Westerly circulation
}

\author{
LIU Xiaokang, "RAO Zhiguo, ZHANG Xiaojian, HUANG Wei, CHEN Jianhui, \\ CHEN Fahu
}

Key Laboratory of Western China's Environmental Systems (Ministry of Education), Lanzhou University, Lanzhou 730000 , China

\begin{abstract}
Proxy records of the oxygen isotopic composition of meteorological precipitation $\left(\delta^{18} \mathrm{O}_{\mathrm{p}}\right)$ preserved in archives such as ice cores, lacustrine carbonates and stalagmite calcite are important for paleoclimatic studies. Therefore, knowledge of the variations and controlling mechanisms of modern $\delta^{18} \mathrm{O}_{p}$ on different time scales is necessary. Here, we investigate the linear correlations between $\delta^{18} \mathrm{O}_{p}$ and corresponding temperature and precipitation on monthly and inter-annual timescales, using data from the Urumqi (1986-2003) and Hotan stations of the Global Network of Isotopes in Precipitation (GNIP), and $\delta^{18} \mathrm{O}$ data from 4 ice cores in the adjacent Tianshan Mountains. Consistent with previous reported results, modern $\delta^{18} \mathrm{O}_{\mathrm{p}}$ variations on a seasonal time scale in the Tianshan region are mainly controlled by a 'temperature effect' (indicated by a significant positive correlation between $\delta^{18} \mathrm{O}_{\mathrm{p}}$ and temperature), with more positive $\delta^{18} \mathrm{O}_{p}$ values occurring in summer. However, on an inter-annual timescale, there is a weak inverse correlation between weighted average annual $\delta^{18} O_{p}$ and annual average temperature at Urumqi station. This finding is supported by the inversely varying trends of $\delta^{18} \mathrm{O}$ data from 4 ice cores in the central and eastern Tianshan Mountains compared to annual average temperatures in the same region during the past $40-50$ years. The data from Urumqi station and the 4 ice cores demonstrate that there is inverse correlation between $\delta^{18} \mathrm{O}_{p}$ and temperature on inter-annual to decadal time scales. Analysis of water vapor sources and pathways for the warm year of 1997 and the cold year of 1988 reveal that relatively more water vapor for the Tianshan region was derived from long-distance transport from high-latitude sources than during the warm year of 1997; and that more water vapor was transported from more proximal sources from mid- to low-latitude areas during the cold year of 1988. In addition, the $\delta^{18} \mathrm{O}_{\mathrm{p}}$ values are more negative in the high latitude areas than those in mid- to low-latitude areas in the Eurasian continent at the upper wind direction of Tianshan Mountains region, according to the weighted averaged warm season (May to September)
\end{abstract}

Received: 2015-01-09 Accepted: 2015-02-28

Foundation: National Natural Science Foundation of China, No.41372181, No.41171091, No.41130102; Fundamental Research Funds for the Central Universities, No.lzujbky-2014-260

Author: Liu Xiaokang (1990-), PhD Candidate, specialized in geochemistry and paleoclimate research.

E-mail: liuxk07@lzu.edu.cn

*Corresponding author: Rao Zhiguo (1978-), PhD and Professor, specialized in geochemistry and paleoclimate research. E-mail: zgrao@lzu.edu.cn 
$\delta^{18} \mathrm{O}_{\mathrm{p}}$ values for 14 GNIP stations in the years 1997 and 1988. Due to the distribution of $\delta^{18} \mathrm{O}_{\mathrm{p}}$ within the Eurasian continent, the relative shift of water vapor sources between warm and cold years convincingly explains the observed variations of $\delta^{18} \mathrm{O}_{p}$ in the Tianshan Mountains region. Therefore, we conclude that variations in $\delta^{18} \mathrm{O}_{p}$ in this region are mainly controlled by changes in water vapor sources which are ultimately caused by northward and southward shifts in the Westerly circulation.

Keywords: Tianshan Mountains; Urumqi; $\delta^{18} \mathbf{O}_{p}$; water vapor sources; Westerly circulation

\section{Introduction}

Influenced by the Westerly circulation, arid central Asia (ACA), especially the Tianshan Mountains region in Xinjiang, Northwest China, is an important study area for paleoclimatic research (Rhodes et al., 1996; Herzschuh, 2006; Chen et al., 2008, 2010; Yang et al., 2011). Research over the past 50 years has shown that there is a trend of increasing precipitation amount in ACA but a decreasing trend in northern China (Huang et al., 2013). During the last millennium, synthesized proxy moisture/precipitation records indicate a drier Medieval Climate Anomaly (MCA) and a wetter Little Ice Age (LIA) in ACA than in monsoonal northern China (Chen et al., 2015). Further, ACA experiences a dry early Holocene, a wetter (less dry) mid-Holocene, and a moderately wet late Holocene, a pattern which is out-of-phase with monsoonal Asia (Chen et al., 2008). These results indicate that the climatic evolution of ACA differs significantly from that of monsoonal Asia (Chen et al., 2009).

The oxygen isotopic composition of meteorological precipitation $\left(\delta^{18} \mathrm{O}_{\mathrm{p}}\right)$ has played an important role in modern climatic and hydrological research. In addition, the $\delta^{18} \mathrm{O}$ signals of various paleoclimatic archives such as ice cores, tree-ring cellulose, lacustrine carbonate and stalagmite calcite, have been considered as proxies for $\delta^{18} \mathrm{O}_{\mathrm{p}}$ and thus have been extensively applied in paleoclimatic research (Thompson et al., 1997; Wang et al., 2001; McCarroll and Loader, 2004; Leng and Marshall, 2004), especially the precisely dated, high-resolution stalagmite oxygen isotope $\left(\delta^{18} \mathrm{O}\right)$ records (Wang et al., 2001). Previously reported results indicate that the seasonal variation of $\delta^{18} \mathrm{O}_{\mathrm{p}}$ in Xinjiang is controlled by a 'temperature effect' (Zheng et al., 1983; Wei and Lin, 1994; Yao et al., 1999; Liu et al., 2009), with more negative $\delta^{18} \mathrm{O}_{\mathrm{p}}$ values in summer and more positive values in winter. However, this seasonally varying pattern of $\delta^{18} \mathrm{O}_{\mathrm{p}}$ is unable to explain the stalagmite $\delta^{18} \mathrm{O}$ record from Kesang Cave $\left(42^{\circ} 52^{\prime} \mathrm{N}, 81^{\circ} 45^{\prime} \mathrm{E}\right.$, $\sim 2000 \mathrm{~m}$ a.s.l.) in the western Tianshan Mountains. During the past $500 \mathrm{ka}$, the Kesang stalagmite record exhibits an inverse correlation between $\delta^{18} \mathrm{O}$ values and Northern Hemisphere summer insolation, showing relatively lower $\delta^{18} \mathrm{O}$ values during higher insolation stages (interglacial), while higher $\delta^{18} \mathrm{O}$ values occur during lower insolation stages (glacial) (Cheng et al., 2012). On the other hand, the explanation of possible incursions of Asian summer monsoon rainfall or related moisture into the region of the Kesang site during times of high insolation, as proposed by Cheng et al. (2012), is facing increasing opposition. Recent research suggests a wetter late Holocene based on the reconstructed humidity of the Xinjiang region (Wang and Feng, 2013); the paleo-summer rainfall inferred from the $\delta^{13} \mathrm{C}$ of peat cellulose from the Chaiwobu peatland (Hong et al., 2013); and the sand dune accumulation chronology of the Bayanbulak Basin (Long et al., 2014). Therefore, it is necessary to clarify the factors influencing stalagmite $\delta^{18} \mathrm{O}$ and associated $\delta^{18} \mathrm{O}_{\mathrm{p}}$ variations in the Tianshan Mountains region.

The stalagmite $\delta^{18} \mathrm{O}$ record is a transformation of the $\delta^{18} \mathrm{O}_{\mathrm{p}}$ signal, following complex interaction processes with surface soil, vegetation, and the surrounding rock. In particular, because of 
the buffering effect of the 'underground reservoir', the final stalagmite $\delta^{18} \mathrm{O}$ signal is biased towards yielding paleoclimatic information on inter-annual or longer time scales (Johnson and Ingram, 2004; Luo and Wang, 2008; Tan, 2011; Genty et al., 2014). In this paper, we use a combination of modern atmospheric precipitation isotope observation data from the Urumqi and Hotan stations available via the Global Network of Isotopes in Precipitation (GNIP) and four previously published ice core $\delta^{18} \mathrm{O}$ records from the adjacent Tianshan Mountains region in order to analyze the various factors, principally temperature and precipitation amount, influencing $\delta^{18} \mathrm{O}_{\mathrm{p}}$ on seasonal and inter-annual time scales. In addition, we investigate the relationships between $\delta^{18} \mathrm{O}_{\mathrm{p}}$ and water vapor sources and transport pathways on an inter-annual time scale in order to determine the most important factors influencing $\delta^{18} \mathrm{O}_{\mathrm{p}}$ in the Tianshan Mountains region.

\section{Study area}

As an important part of ACA, Xinjiang consists of the Kunlun Mountains, the Tarim Basin, the Tianshan Mountains, the Junggar Basin and the Altay Mountains (Figure 1). The east-west trend distribution of the Tianshan Mountains divides Xinjiang into northern and southern parts. The prominent feature of the climate of Xinjiang is the uneven spatial and temporal distribution of the rainfall. Generally, there is less rainfall in the basins than in the mountains and in addition there are frequent extreme precipitation events, such as rainstorms and snowstorms (Yang, 2003). The vegetation of the region is sparsely distributed and the overall ecological environment is very fragile. The higher precipitation in the mountains constitutes the major water source for Xinjiang. Significantly more rainfall occurs in summer than in winter, as shown in Figures 2a and 2b. Although this seasonal rainfall pattern is similar to that of monsoonal Asia, the climate of Xinjiang is dominated by the Westerly circulation (Chen et al., 2008, 2009, 2010). Over the past 50 years,

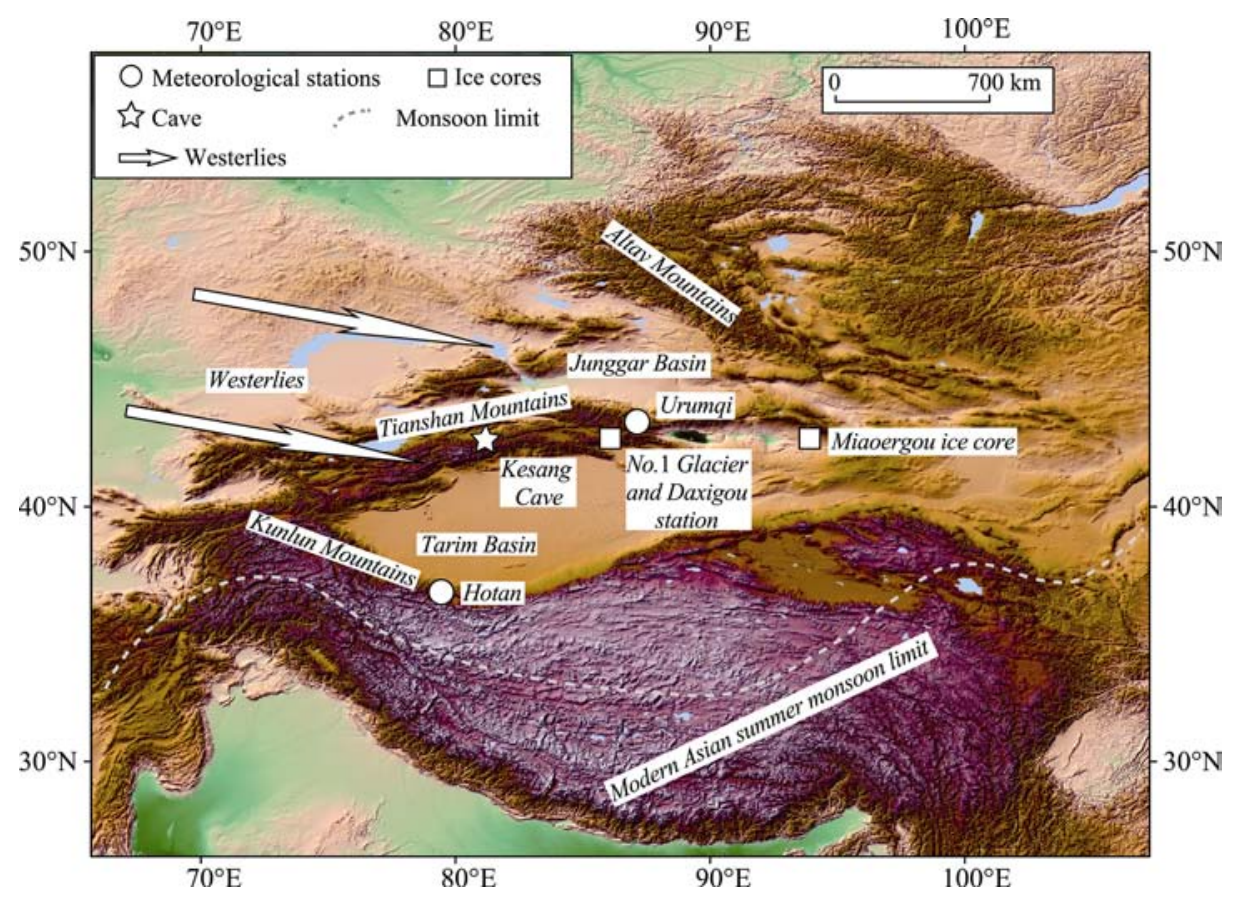

Figure 1 The study area and climatic records (the modern Asian summer monsoon limit is based on Chen et al., 2008) 
observations of temperature and precipitation in Xinjiang indicate a pattern of fluctuating but overall rising values (Dai et al., 2007) with a rapid increase of temperature from the late 1980s onwards. With the rapid warming, precipitation, glacial melting and runoff have all increased significantly; and in addition, lake levels are rising and the vegetation conditions are improving. Consequently, Shi et al. (2007) have proposed a climatic transition from a dry-warm to a wet-warm pattern in the arid areas of northwestern China. Moreover, virtually the entire ACA region is experiencing a trend of increasing precipitation (Huang et al., 2013). Increasing water vapor transport from high latitude regions to Xinjiang is the main cause of the humidifying trend, and is taking place against the background of global warming, especially the rapid warming occurring at high latitudes (Dai et al., 2006). The present paper investigates the relationships between $\delta^{18} \mathrm{O}_{\mathrm{p}}$ and water vapor sources and pathways in order to improve understanding of climate change in the Tianshan Mountains region.

\section{Data and analytical methods}

\subsection{Data}

The $\delta^{18} \mathrm{O}_{\mathrm{p}}$ data used in this paper was downloaded from the GNIP database, established by the International Atomic Energy Agency (IAEA) and the World Meteorological Organization (WMO) since 1961. Among the GNIP sites, a total of three stations are located in ACA: Urumqi, Hotan and Tashkent. Unfortunately, the $\delta^{18} \mathrm{O}_{\mathrm{p}}$ observations for Tashkent only commenced in 1971, thereby somewhat limiting our analysis of the $\delta^{18} \mathrm{O}_{\mathrm{p}}$ variations for this region. In addition, the observation period for the Urumqi station is from 1986 to 2003, with no data from 2004 to the present. During the observation period, data are absent for 1993-1994, 1999-2000; and in addition, the years 1992, 1995 and 1998 lack observational data for more than 4 months. Thus, the available dataset comprises 1986-1991, 1996-1997 and 2001-2003, a total of 11 years. At Hotan station, there are five years of continuous observational data for analysis (1988-1992) (see Table 1). Therefore, we choose Urumqi station as representative of the Tianshan Mountains region and used the data from Hotan station for a supplementary analysis of the varying characteristics of $\delta^{18} \mathrm{O}_{\mathrm{p}}$ on seasonal and inter-annual time scales (Figure 2).

In addition to the observational data, we selected three ice core $\delta^{18} \mathrm{O}$ records $(1962-1997)$ from No.1 glacier at the headwaters of Urumqi River $\left(43^{\circ} 03^{\prime} \mathrm{N}, 86^{\circ} 29^{\prime} \mathrm{E}\right)$ in the central Tianshan Mountains, and the ice core $\delta^{18} \mathrm{O}$ record (1953-2004) from Miaoergou glacier from the Karlik Mountain $\left(43^{\circ} 03^{\prime} \mathrm{N}, 9^{\circ} 19^{\prime} \mathrm{E}\right)$ from the eastern Tianshan Mountains, in order to provide supporting evidence. In order to analyze relationships between the varying characteristics of $\delta^{18} \mathrm{O}_{\mathrm{p}}$ and water vapor sources, and to investigate possible differences in water vapor sources between warm and cold years, we used observational temperature and precipitation data from the China Surface Climate Dataset (Monthly) (1951-2011) from Urumqi station. In addition, we calculated the weighted average warm season (May to September) $\delta^{18} \mathrm{O}_{\mathrm{p}}$ values from 12 other GNIP stations in the Eurasian continent for the years 1997 and 1988 (Table 1 and Figure 5) in order to compare the different pathways of water vapor transport to the Tianshan Mountains region.

\subsection{Analytical methods}

The original data monthly $\delta^{18} \mathrm{O}_{\mathrm{p}}$ observations from GNIP are obtained by averaging the total rainfall for one month, and thus the monthly $\delta^{18} \mathrm{O}_{\mathrm{p}}$ value represents the average for one month. In order to simulate the averaged nature of the $\delta^{18} \mathrm{O}_{\mathrm{p}}$ record of geological archives such as ice cores and speleothems, we used the monthly values of $\delta^{18} \mathrm{O}_{p}$ and precipitation amount in order to 
Table 1 Details of the localities and $\delta^{18} \mathrm{O}_{\mathrm{p}}$ data for 14 GNIP stations in the Eurasian continent and their weighted average warm season (May to September) $\delta^{18} \mathrm{O}_{\mathrm{p}}$ values in 1997 and 1988

\begin{tabular}{|c|c|c|c|c|c|c|c|c|c|}
\hline $\begin{array}{l}\text { GNIP } \\
\text { Code }\end{array}$ & Station name & Country & $\begin{array}{l}\text { Lat. } \\
\left({ }^{\circ} \mathrm{N}\right)\end{array}$ & $\begin{array}{l}\text { Long. } \\
\left({ }^{\circ} \mathrm{E}\right)\end{array}$ & $\begin{array}{c}\text { Observing } \\
\text { period }\end{array}$ & $\begin{array}{c}\text { Weighted average } \\
\text { warm season } \delta^{18} \mathrm{O}_{\mathrm{p}} \text { of } \\
1997(\% \text {, VSMOW) }\end{array}$ & $\begin{array}{l}\text { Months of } \\
\text { observation }\end{array}$ & $\begin{array}{c}\text { Weighted average warm } \\
\text { season } \delta^{18} \mathrm{O}_{\mathrm{p}} \text { of } 1988 \\
(\% \text {, VSMOW })\end{array}$ & $\begin{array}{l}\text { Months of } \\
\text { observation }\end{array}$ \\
\hline 1713000 & Ankara (central) & Turkey & 39.95 & 32.88 & 1963-2009 & -5.78 & May - Aug. & -5.88 & May - Aug. \\
\hline 2221700 & Kandalaksa & Russian Federation & 67.15 & 32.35 & 1996-2000 & -12.10 & May - Sep. & - & - \\
\hline 2606300 & St. Petersburg & Russian Federation & 59.97 & 30.30 & 1980-1990 & - & - & -10.70 & May - Sep. \\
\hline 2642200 & Riga & Latvia & 56.97 & 24.07 & 1969-1989 & - & - & -6.35 & May - Sep. \\
\hline 2719600 & Kirov & Russian Federation & 58.65 & 49.62 & 1980-2000 & -9.53 & May - Sep. & - & - \\
\hline 2740200 & Kalinin & Russian Federation & 56.90 & 35.90 & 1980-1989 & - & - & -7.61 & May - Sep. \\
\hline 2822500 & Perm & Russian Federation & 58.01 & 56.18 & 1973-1990 & - & - & -9.17 & May - July \\
\hline 2961200 & Barabinsk & Russian Federation & 55.33 & 78.37 & 1996-2000 & -8.90 & May - July, Sep. & - & - \\
\hline 3400900 & Terney & Russian Federation & 51.73 & 36.27 & 1996-2000 & -9.75 & July - Sep. & - & - \\
\hline 3488000 & Astrakhan & Russian Federation & 46.25 & 48.03 & 1980-2000 & -5.06 & May - July, Sep. & -4.99 & May - Sep. \\
\hline 3748400 & Batumi & Georgia & 41.65 & 41.63 & 1980-1990 & - & - & -5.20 & Aug. - Sep. \\
\hline 4094900 & Kabul (Karizimir) & Afghanistan & 34.57 & 69.21 & 1962-1991 & - & - & 0.07 & May - June, Aug. \\
\hline 5182800 & Hotan & China & 37.13 & 79.93 & 1988-1992 & - & - & -3.04 & May - Sep. \\
\hline 5182801 & Urumqi & China & 43.78 & 87.62 & 1986-2003 & -8.64 & May - Aug. & -6.39 & May - Sep. \\
\hline
\end{tabular}

Note: “_” means no data in the table. 
calculate the weighted average $\delta^{18} \mathrm{O}_{\mathrm{p}}$ values on an annual and warm season and cold season basis. The formula used is

$$
\delta^{18} \mathrm{O}_{w}=\sum_{i=1}^{n} \delta^{18} \mathrm{O}_{i} \cdot P_{i} / \sum_{i=1}^{n} P_{i}
$$

where $\delta^{18} \mathrm{O}_{w}$ denotes the weighted average $\delta^{18} \mathrm{O}_{\mathrm{p}}$ value, and $\delta^{18} \mathrm{O}_{i}$ and $P_{i}$ respectively represent the $\delta^{18} \mathrm{O}_{\mathrm{p}}$ value and precipitation amount for month $i$.

According to the GNIP database, the annual average temperature is $7.4^{\circ} \mathrm{C}$ and the annual total precipitation amount is $296.2 \mathrm{~mm}$ at Urumqi. For the period of observation, 1997 is the warmest year and 1988 is the coldest year. Next we calculated the values for warm season water vapor flux for 1997 and 1988 in order to analyze differences in the relative water vapor sources. Thus the water vapor flux for 1997 minus that for 1988 represents the relative water vapor sources for 1997; and the water vapor flux for 1988 minus 1997 represents the relative water vapor sources for 1988. All of the water vapor fluxes are calculated as whole layer moisture flux for the atmospheric layer corresponding to 300-1000 hPa from the ground. The differences between precipitation, temperature and $\delta^{18} \mathrm{O}_{\mathrm{p}}$ values between the years 1997 and 1988 are shown in Table 2. Combining these data with the weighted average warm season $\delta^{18} \mathrm{O}_{\mathrm{p}}$ values for 14 GNIP stations in the Eurasian continent (Table 1 and Figure 5), the relative differences of water vapor sources provide information about the factors influencing $\delta^{18} \mathrm{O}_{\mathrm{p}}$ in the study area.

Table 2 Annual precipitation, annual and warm season (May to September) average temperature, and weighted average annual and warm season $\delta^{18} \mathrm{O}_{\mathrm{p}}$ values for 1997 and 1988 at Urumqi station

\begin{tabular}{cccccc}
\hline Year & $\begin{array}{c}\text { Annual pre- } \\
\text { cipitation } \\
\text { amount }(\mathrm{mm})\end{array}$ & $\begin{array}{c}\text { Annual average } \\
\text { temperature } \\
\left({ }^{\circ} \mathrm{C}\right)\end{array}$ & $\begin{array}{c}\text { Weighted average } \\
\text { annual } \delta^{18} \mathrm{O}_{\mathrm{p}}(\%) \\
\text { VSMOW) }\end{array}$ & $\begin{array}{c}\text { Warm season } \\
\text { average tempera- } \\
\text { ture }\left({ }^{\circ} \mathrm{C}\right)\end{array}$ & $\begin{array}{c}\text { Weighted average } \\
\text { warm season } \delta^{18} \mathrm{O}_{\mathrm{p}} \\
(\% \text {, VSMOW) }\end{array}$ \\
\hline 1997 & 156 & 10.13 & -11.33 & 25.72 & -8.64 \\
1988 & 374 & 6.33 & -7.49 & 19.40 & -6.39 \\
\hline
\end{tabular}

\section{Results}

\subsection{Seasonal variations of $\delta^{18} \mathrm{O}_{\mathrm{p}}$}

As shown in Figure 2, the $\delta^{18} \mathrm{O}_{\mathrm{p}}$ values at Urumqi station are more positive in summer and more negative in winter, with a shift of about $\sim 15 \%$ o (Figure $2 \mathrm{a}$ ). The most positive $\delta^{18} \mathrm{O}_{\mathrm{p}}$ values occur in August and the most negative $\delta^{18} \mathrm{O}_{\mathrm{p}}$ values occur in December to February of each year. These trends are similar to the seasonal variations of $\delta^{18} \mathrm{O}_{\mathrm{p}}$ observed at Hotan station (Figure 2b). Calculation of the linear regressions for monthly $\delta^{18} \mathrm{O}_{\mathrm{p}}$ and monthly average temperature and monthly precipitation reveals a strong positive correlation between monthly $\delta^{18} \mathrm{O}_{\mathrm{p}}$ and monthly average temperature at Urumqi ( $r=0.99, p<0.01$, Figure 2c) and Hotan ( $r=0.97, p<0.01$, Figure $2 \mathrm{~d})$. In addition, there are significant linear correlations between monthly $\delta^{18} \mathrm{O}_{\mathrm{p}}$ and monthly precipitation amount at both Urumqi and Hotan ( $r=0.84$ and $r=0.68$ ), at the $99 \%$ and $95 \%$ confidence levels, respectively (Figures $2 \mathrm{e}$ and $2 \mathrm{f}$ ). From the results shown in Figures $2 \mathrm{a}$ and $2 \mathrm{~b}$, we conclude that the variation of $\delta^{18} \mathrm{O}_{\mathrm{p}}$ values is consistent with variations in monthly average temperature, rather than with monthly precipitation amount. It is clear that the precipitation amount decreases in August, but that both $\delta^{18} \mathrm{O}_{\mathrm{p}}$ and temperature continue to increase until September, which further suggests that there is a close relationship between $\delta^{18} \mathrm{O}_{\mathrm{p}}$ and temperature on a seasonal time scale.

From the foregoing, it is apparent that in ACA temperature change dominates the variation of $\delta^{18} \mathrm{O}_{\mathrm{p}}$ on a seasonal time scale, as indicated by previous studies (Yao et al., 1999; Tian et al., 
2007; Li and Zhou, 2007; Liu et al., 2009). The $\delta^{18} \mathrm{O}$ variations of snow and ice from the Tianshan Mountains and the Altay Mountains also confirm the dominating effect of temperature (Aizen et al., 2006). In addition, observations of precipitation events from June 1995 until June 1996 (Hou et al., 1999), and continuous monitoring of precipitation from June 1997 until August 1998 (Yao et al., 1999) in Daxigou Meteorological Station, close to No.1 glacier at the headwaters Urumqi River in the central Tianshan Mountains, reveal a significant positive correlation between $\delta^{18} \mathrm{O}_{\mathrm{p}}$ and temperature. Recently published observational data of $\delta^{18} \mathrm{O}_{\mathrm{p}}$ and temperature from three meteorological stations in the Urumqi River basin (Feng et al., 2013) also confirm a significant 'temperature effect' on the variations of $\delta^{18} \mathrm{O}_{\mathrm{p}}$ in the Tianshan Mountains region on a seasonal time scale.
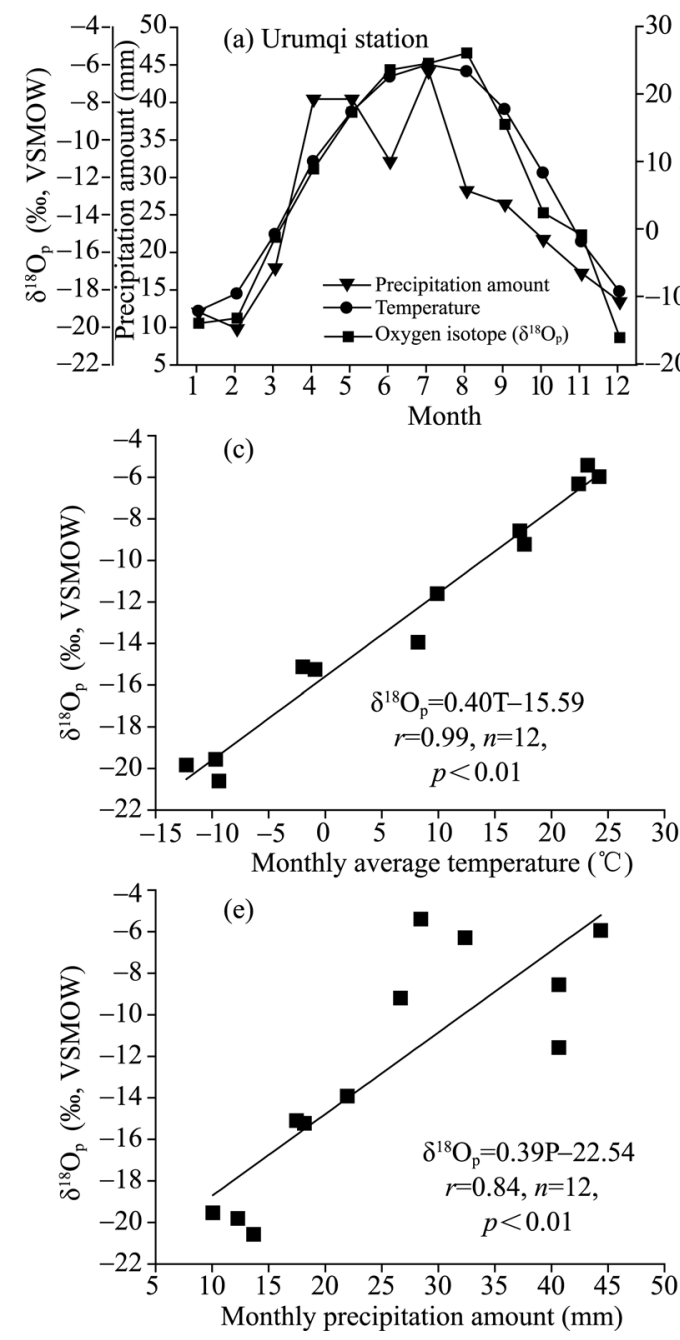

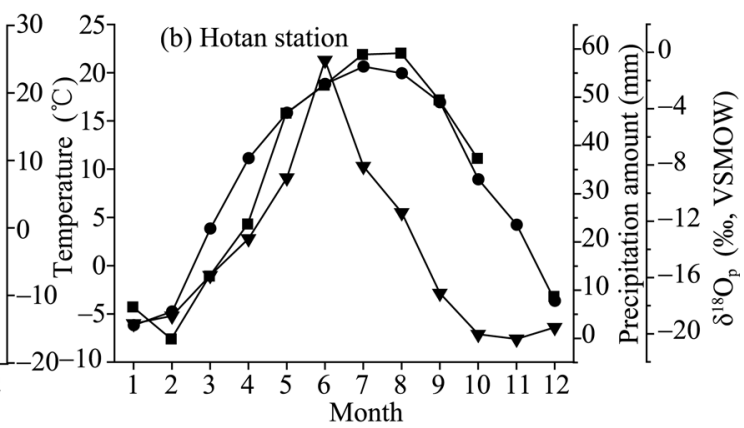

(d)
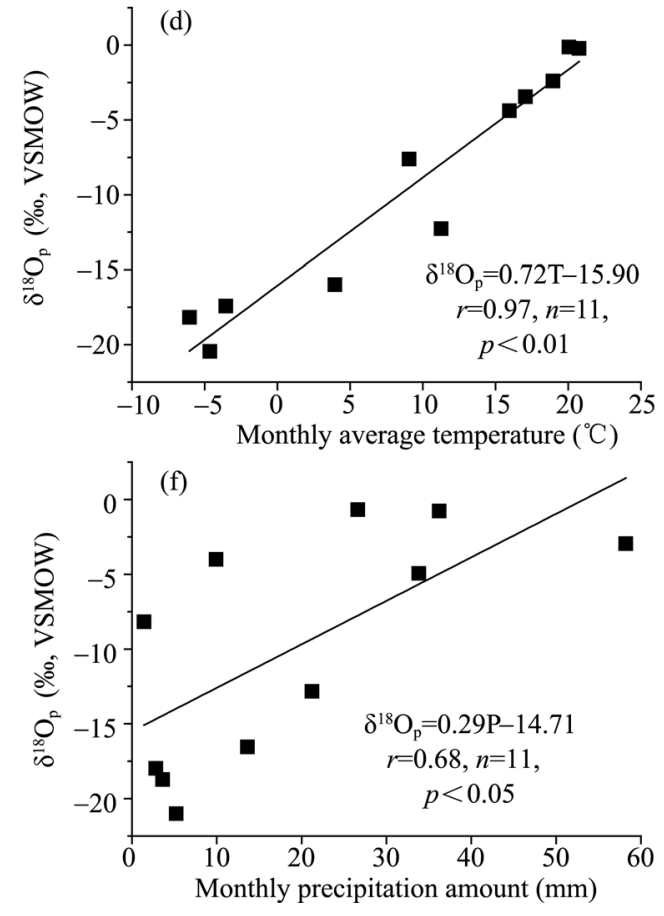

Figure 2 Variations of monthly $\delta^{18} \mathrm{O}_{\mathrm{p}}$, temperature and precipitation at Urumqi (a) and Hotan (b) stations; linear correlations between monthly $\delta^{18} \mathrm{O}_{\mathrm{p}}$ and temperature at Urumqi (c) and Hotan (d) stations; and linear correlations between monthly $\delta^{18} \mathrm{O}_{\mathrm{p}}$ and precipitation amount at Urumqi (e) and Hotan (f) stations

\subsection{Inter-annual variations of $\delta^{18} \mathrm{O}_{\mathrm{p}}$}

Calculating the linear regression of the 11-year observational dataset of weighted average annual 
$\delta^{18} \mathrm{O}_{\mathrm{p}}$ and annual average temperature and annual precipitation at Urumqi station reveals a weak inverse correlation between weighted average annual $\delta^{18} \mathrm{O}_{\mathrm{p}}$ and annual average temperature ( $r=$ -0.28 , Figure 3a); however, there remains a weak positive correlation with annual precipitation amount ( $r=0.33$, Figure $3 \mathrm{~b}$ ). Although there are only 5 years of observations, there is also a weak inverse correlation between weighted average annual $\delta^{18} \mathrm{O}_{\mathrm{p}}$ and annual average temperature at Hotan. Clearly the dominating effect of temperature on $\delta^{18} \mathrm{O}_{p}$ on a seasonal time scale is no longer evident; rather, there is an inverse correlation on an inter-annual time scale.
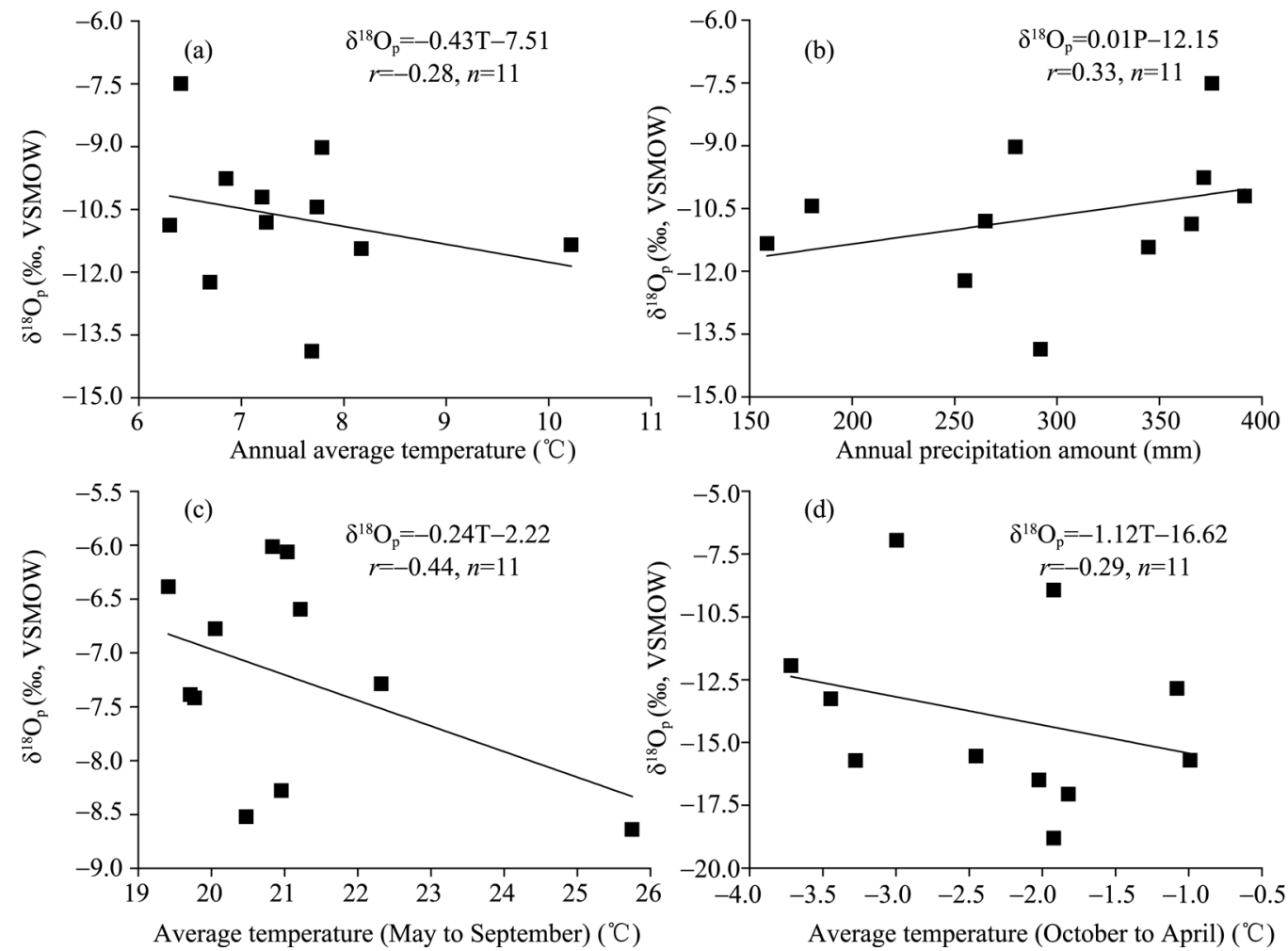

Figure 3 Linear correlations between weighted average annual $\delta^{18} \mathrm{O}_{\mathrm{p}}$ and mean annual temperature (a); weighted average annual $\delta^{18} \mathrm{O}_{\mathrm{p}}$ and annual precipitation amount (b); weighted average warm season (May to September) $\delta^{18} \mathrm{O}_{\mathrm{p}}$ and warm season average temperature (c); weighted average cold season (October to April) $\delta^{18} \mathrm{O}_{\mathrm{p}}$ and cold season average temperature (d) at Urumqi station

According to the observational data from the China Surface Climate Dataset (Monthly), temperature rises above $0^{\circ} \mathrm{C}$ in May and then temperatures remain warm until the onset of snowfall in October in the Xinjiang region. Thus the interval during which freezing temperatures obtain is October to April. Therefore, in the Tianshan Mountains region and Xinjiang, we define May to September, the main rainfall months, as the warm season; and October to April as the cold season. Next we calculated linear correlations between annual average temperature and $\delta^{18} \mathrm{O}_{\mathrm{p}}$ for the warm season and the cold season at Urumqi station. The results indicate a stronger inverse correlation between weighted average $\delta^{18} \mathrm{O}_{\mathrm{p}}$ and warm season average temperature $(r=-0.44$, Figure $3 c)$ than for both the annual average temperature ( $r=-0.28$, Figure $3 a)$, and the cold season average temperature ( $r=-0.29$, Figure $3 \mathrm{~d}$ ). Results for the No.1 glacier also reveal a stronger inverse correlation between ice core $\delta^{18} \mathrm{O}$ and ablation season average temperature (Hou et al., 2006), which supports the close relationship between $\delta^{18} \mathrm{O}_{\mathrm{p}}$ and warm season average tempera- 
ture. In addition, previous work suggests that the rainfall during the warm season (May to September) contributes most of the total annual precipitation in Xinjiang (Wang and Ren, 2005). This is demonstrated by calculating the rainfall percentage during the warm season at Urumqi ( $\sim 56 \%)$ and Hotan ( 78\%) stations (Figures 2a and $2 \mathrm{~b})$. More importantly, rainfall during the cold season (mainly snow) remains frozen on the ground and surface water is unable to infiltrate and contribute to cave precipitation. Therefore, the annual $\delta^{18} \mathrm{O}_{\mathrm{p}}$ values in the Tianshan Mountains region are mainly determined by the warm season $\delta^{18} \mathrm{O}_{\mathrm{p}}$, and thus we surmise that the warm season $\delta^{18} \mathrm{O}_{\mathrm{p}}$ is the main signal contributor to the cave stalagmite $\delta^{18} \mathrm{O}$ record in this region.

\subsection{Ice core $\delta^{18} \mathrm{O}$ variations}

Because of the lack of long-term observational data, we used the ice core $\delta^{18} \mathrm{O}$ record as a proxy for the long-term $\delta^{18} \mathrm{O}_{\mathrm{p}}$ signal in order to try to verify the observed inverse correlation between $\delta^{18} \mathrm{O}_{\mathrm{p}}$ and temperature on an inter-annual time scale in the Tianshan Mountains region. Located in the central Tianshan Mountains, three ice core $\delta^{18} \mathrm{O}$ records (TS-1, TS-2 and TS-3) from No.1 glacier at the headwaters of the Urumqi River provide a proxy record of variations in $\delta^{18} \mathrm{O}_{\mathrm{p}}$ during the past 40 years (Hou et al., 1998, 2006). As shown in Figure 4a, the ice core $\delta^{18} \mathrm{O}$ records reveal a trend of declining $\delta^{18} \mathrm{O}$ over time, which is the inverse of the rising trend of measured annual temperature at both nearby Daxigou Meteorological Station (Hou et al., 1998, 2006) and the entire Xinjiang region (Dai et al., 2007; Zhao et al., 2011). Thus these observed relationships between ice core $\delta^{18} \mathrm{O}$ and measured temperature records confirm the inverse correlation between $\delta^{18} \mathrm{O}_{\mathrm{p}}$ and temperature noted in section 4.2.

The upper $16.83 \mathrm{~m}$ (1953 to 2004) of the $\delta^{18} \mathrm{O}$ record of Miaoergou ice core 2, from the Karlik Mountains in the eastern part of the Tianshan Mountains, is characterized by a fluctuating pattern of $\delta^{18} \mathrm{O}_{\mathrm{p}}$ variations. Although the ice core $\delta^{18} \mathrm{O}$ record could be affected by melting and post-depositional diffusion of water vapor, the evidence indicates that these effects are limited to individual annual ice layers (Song et al., 2011), and thus they should have no influence on the inter-annual relationships between ice core $\delta^{18} \mathrm{O}$ and climatic factors. Overall, the $\delta^{18} \mathrm{O}$ record exhibits a trend of declining values from bottom to top, which is the inverse of the trend of rising average annual temperature observed at nearby Balikun and Yiwu stations (Song et al., 2011), for the entire Xinjiang region (Dai et al., 2007; Zhao et al., 2011), and for ACA as a whole under the influence of global warming (Chen et al., 2009). Therefore, it is clear that there is an inverse relationship between regional temperature and $\delta^{18} \mathrm{O}_{\mathrm{p}}$ variations in the Miaoergou ice core (Figure 4b).

Although there is only a weak inverse correlation between annual average $\delta^{18} \mathrm{O}_{\mathrm{p}}$ and temperature, the reality of the relationship is supported by the observed inverse trends of variation of ice core $\delta^{18} \mathrm{O}$ and temperature in the central and eastern Tianshan Mountains during the past 40-50 years. Overall, the data point to the reality of an inverse relationship between $\delta^{18} \mathrm{O}_{\mathrm{p}}$ and temperature in the Tianshan Mountains region on inter-annual to inter-decadal time scales.

\section{Discussion}

\subsection{Correlation between $\delta^{18} \mathrm{O}_{\mathrm{p}}$ and temperature on seasonal and inter-annual time scales}

On a seasonal time scale, the monthly $\delta^{18} \mathrm{O}_{\mathrm{p}}$ values are more positive in summer and more negative in winter. The seasonal shift is $\sim 15 \%$ ond is dominated by a 'temperature effect' in the Tianshan Mountains region. This pattern of seasonal variation of $\delta^{18} \mathrm{O}_{\mathrm{p}}$ differs significantly to 

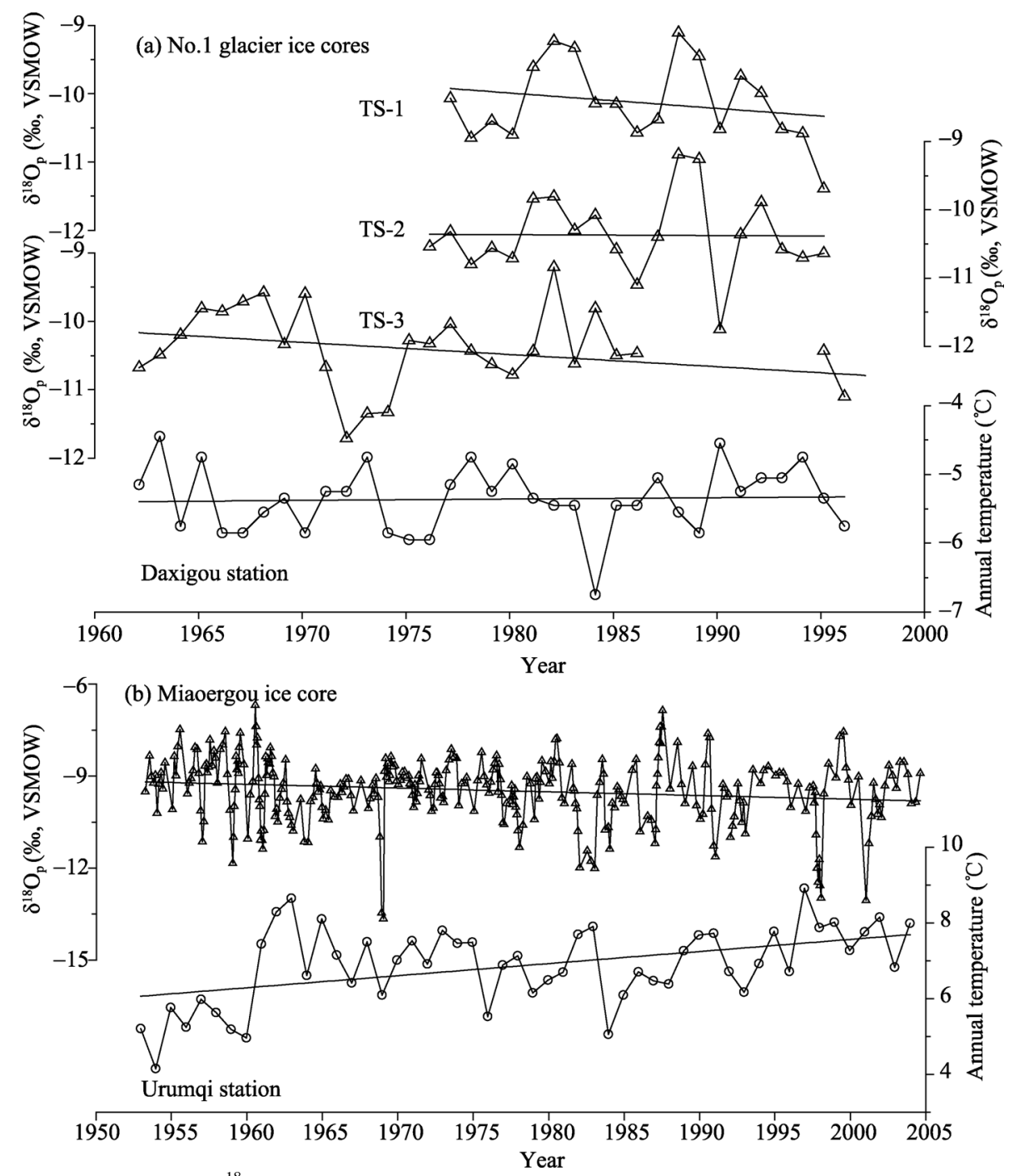

Figure 4 Comparison of $\delta^{18} \mathrm{O}$ records from three ice cores (TS-1, TS-2, TS-3) from No.1 glacier in the central Tianshan Mountains with annual average temperature data from the nearby Daxigou Meteorological Station (a. original data from Hou et al. $(1998,2006)$ ); comparison of the Miaoergou ice core $\delta^{18} \mathrm{O}$ record from the eastern Tianshan Mountains (original data from Song et al. (2011)) with annual average temperature data from Urumqi station (b. original data from China Surface Climate Dataset (Monthly)). (Bold lines indicate the long-term trends of each dataset)

that in monsoonal Asia, where $\delta^{18} \mathrm{O}_{\mathrm{p}}$ is more negative in summer and more positive in winter. Therefore there is a mismatch with the variation of stalagmite $\delta^{18} \mathrm{O}$ records, such as from Kesang Cave, Xinjiang, which are relatively more negative during interglacial stages and more positive during glacial stages (Cheng et al., 2012). On the other hand, the inverse correlation on an inter-annual time scale between $\delta^{18} \mathrm{O}_{\mathrm{p}}$ and temperature evident in the observational data and the ice core $\delta^{18} \mathrm{O}$ records demonstrates that the $\delta^{18} \mathrm{O}_{\mathrm{p}}$ of the Tianshan Mountains region is primarily controlled by factors other than temperature or precipitation amount.

\subsection{Changes in moisture source in Xinjiang}

Water vapor sources and pathways are additional factors potentially influencing $\delta^{18} \mathrm{O}_{\mathrm{p}}$ variations 
on an inter-annual time scale and we now briefly review previous research on this topic based on statistical and reanalysis data of meteorological stations in the Xinjiang region. By analyzing the hourly GMS-5 satellite water vapor data from April 1998 to October 2000, Wang et al. (2001) proposed three major pathways of water vapor transport to Xinjiang: from the southwest, west and northwest with the westerly direction being most important. In addition, Liu and Yang (2010) calculated water vapor flux and moisture budgets for the Xinjiang region from 1948 to 2007 and concluded that water vapor transport was mainly affected by three water vapor transport routes: a northwesterly route from Siberia and Mongolia; a southerly route from the Bay of Bengal; and finally the transport of water vapor from the Atlantic by the Westerlies. It has also been shown that the water vapor sources of Xinjiang vary seasonally, with northern and northwestern sources dominating in summer and a southwestern source dominating in winter (Dai et al., 2006; Shi and Sun, 2008).

Next, in order to clarify the relationship between water vapor sources and $\delta^{18} \mathrm{O}_{\mathrm{p}}$ variations, we review the distribution and range of warm season $\delta^{18} \mathrm{O}_{\mathrm{p}}$ values from 14 GNIP stations in the Eurasian continent at the upper wind direction of the Tianshan Mountains region under different circulation and climatic scenarios. The results indicate that the $\delta^{18} \mathrm{O}_{\mathrm{p}}$ values are more negative at high-latitudes and more positive at mid- to low-latitudes, with a shift of 5\%-10\% (Table 1 and Figure 5). It is useful to address the issue of the inverse correlation between annual average $\delta^{18} \mathrm{O}_{\mathrm{p}}$ and temperature by comparing the differences between warm season water vapor sources in relatively warm and cold years. The results (Figure 5) suggest that in 1997 the study area received more water vapor via long-distance transport from high latitude regions (which resulted in more negative $\delta^{18} \mathrm{O}_{\mathrm{p}}$ values), while in 1988 more water vapor was derived from mid- to low-latitude sources (which resulted in more negative $\delta^{18} \mathrm{O}_{\mathrm{p}}$ values). Consequently, the inverse correlation between annual average $\delta^{18} \mathrm{O}_{\mathrm{p}}$ and temperature reflect the relative variation of different water vapor sources and pathways in the context of different atmospheric circulation patterns during warm and cold years.

\subsection{Impact of water vapor sources on $\delta^{18} \mathrm{O}_{\mathrm{p}}$ variations}

Consideration of the different water vapor sources leads to the conclusion that the variations of $\delta^{18} \mathrm{O}_{\mathrm{p}}$ are essentially caused by northward and southward shifts in the Westerlies. We infer that the $\delta^{18} \mathrm{O}_{\mathrm{p}}$ values are more negative due to a greater proportion of relatively long-distance water vapor transport from high-latitude sources during intervals when the Westerlies shift to a more northerly location. In contrast, more positive $\delta^{18} \mathrm{O}_{\mathrm{p}}$ values result from shorter-distance transport of moisture from mid- to low-latitude sources when the Westerlies shift to a more southerly location. Therefore, the $\delta^{18} \mathrm{O}_{\mathrm{p}}$ signals recorded on inter-annual to longer time scales in geological archives, such as stalagmites, are determined essentially by the northern and southern positions of the Westerlies. Therefore we conclude that the longer-distance water vapor transport from high-latitude regions increases when the temperatures are higher and the Westerlies shift a more northerly location, in turn resulting in more negative $\delta^{18} \mathrm{O}_{\mathrm{p}}$ and stalagmite $\delta^{18} \mathrm{O}$ values. When temperature falls and the Westerlies shift southwards, the proportion of shorter-distance water vapor transport from mid- to low- latitude area increases, resulting in more positive $\delta^{18} \mathrm{O}_{\mathrm{p}}$ and stalagmite $\delta^{18} \mathrm{O}$ values. Our inference may explain why the Kesang Cave stalagmite $\delta^{18} \mathrm{O}$ values are more negative during the relatively warm early and mid-Holocene (Marcott et al., 2013) than during the relatively cold late Holocene (Cheng et al., 2012). As a result, the hypothesis that possible incursions of Asian summer monsoon rainfall into Kesang Cave during times of high insolation (Cheng et al., 2012) is questionable. 

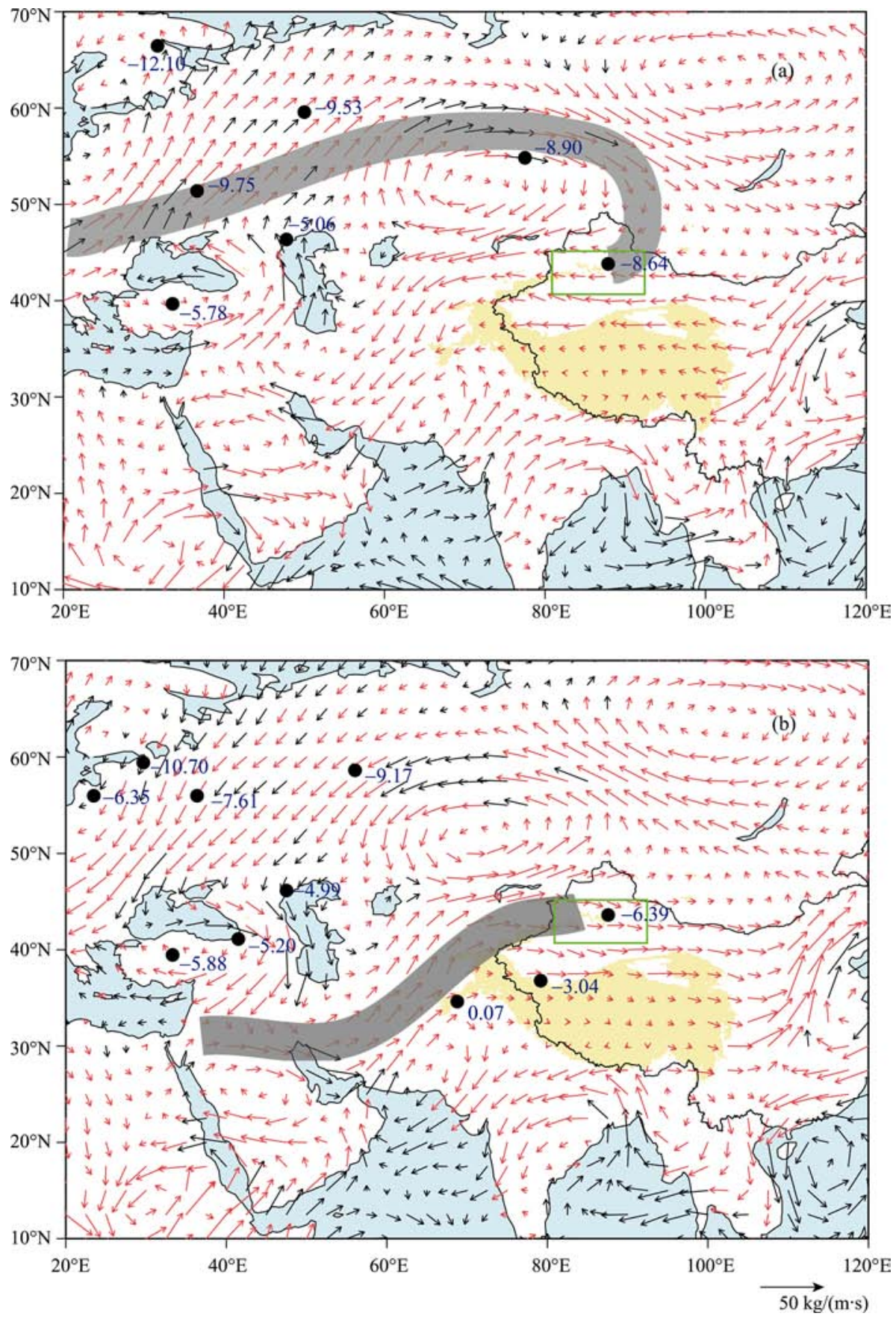

Figure 5 Differences in water vapor sources for the Tianshan Mountains region between the warm season of 1997 (warm year) and 1988 (cold year) and the corresponding weighted average warm season $\delta^{18} \mathrm{O}_{\mathrm{p}}$ values of 14 GNIP stations in the Eurasian continent. (a. warm season water vapor flux of 1997 minus that of 1988; b. warm season water vapor flux of 1988 minus that of 1997. Red arrows indicate the relative water vapor changes significant at the 99\% level; grey bands indicate the main pathways of relative water vapor sources; black dots indicate the GNIP stations; blue numbers denote the weighted average warm season $\delta^{18} \mathrm{O}_{\mathrm{p}}$ values in the years 1997 and 1988 (data are shown in Tables 1 and 2); and the green boxes show the location of the Tianshan Mountains region 
Recent studies have also found that the stalagmite $\delta^{18} \mathrm{O}$ records in monsoonal Asia respond to ENSO variations (a 'circulation effect') on decadal and centennial time scales. This implies that the negative and positive shifts in stalagmite $\delta^{18} \mathrm{O}$ are caused by variations in the transport of water vapor from more distal to more proximal sources (Tan, 2011, 2014), or that they reflect differences in precipitation patterns and water vapor pathways (Dayem et al., 2010). On an orbital time scale, in monsoonal China stalagmite $\delta^{18} \mathrm{O}$ records spanning the Holocene are considered to be an indicator of the intensity of the Indian Summer Monsoon (ISM) rather than the East Asian Summer Monsoon (EASM) (Yang et al., 2014; Chen et al., 2014). During the last interglacial period, the differences between loess-paleosol profiles and stalagmite records from monsoonal China indicate that stalagmite $\delta^{18} \mathrm{O}$ is not a direct index of EASM evolution (Rao et al., 2014). The recently published reconstruction of air mass history at Eagle Cave, central Spain, in the mid-latitude region, highlights the importance of different moisture sources in controlling stalagmite $\delta^{18} \mathrm{O}$ composition (Krklec et al., 2014). In fact, our hypothesis that different water sources dominate the variations of $\delta^{18} \mathrm{O}_{\mathrm{p}}$ and $\delta^{18} \mathrm{O}$ in the Tianshan Mountains region is similar to the basic principle of the 'circulation effect' whereby long-distance and short-distance transport of water vapor controls stalagmite $\delta^{18} \mathrm{O}$ variations in monsoonal Asia (Tan, 2014). On inter-annual to inter-decadal time scales, the mechanism whereby northern-to-southern shifts of the Westerlies control $\delta^{18} \mathrm{O}_{\mathrm{p}}$ variations in the Tianshan Mountains region could appropriately be named the 'Westerly circulation effect'.

\section{Conclusions}

In order to better assess the possible factors influencing $\delta^{18} \mathrm{O}_{\mathrm{p}}$ in the Tianshan Mountains region, and potentially in ACA as a whole, we used observations of $\delta^{18} \mathrm{O}_{\mathrm{p}}$ for Urumqi (1986-2003), the longest and most complete observing sequence in ACA, for Hotan (1988-1992), and for 12 other GNIP stations in the Eurasian continent. We also compared these data with 4 ice core $\delta^{18} \mathrm{O}$ records from the adjacent Tianshan Mountains. Our major concern was to analyze the variations of $\delta^{18} \mathrm{O}_{\mathrm{p}}$ and their influencing factors on seasonal and inter-annual time scales, principally the correlation between $\delta^{18} \mathrm{O}_{\mathrm{p}}$ and temperature. Our main conclusions are as follows:

(1) On a seasonal time scale, the monthly $\delta^{18} \mathrm{O}_{\mathrm{p}}$ values are more positive in summer and more negative in winter, with a shift of $\sim 15 \%$. The correlations between monthly $\delta^{18} \mathrm{O}_{\mathrm{p}}$ and temperature are $r=0.99(n=12, p<0.01)$ and $r=0.97(n=11, p<0.01)$ at Urumqi and Hotan, respectively. The $\delta^{18} \mathrm{O}_{\mathrm{p}}$ values are dominated by a 'temperature effect' in the Tianshan Mountains region. However, the stalagmite record exhibits more negative $\delta^{18} \mathrm{O}$ values during interglacial stages and more positive $\delta^{18} \mathrm{O}$ values during glacial stages ( $\sim 6 \%$ amplitude). This difference cannot be explained by the seasonal varying pattern of $\delta^{18} \mathrm{O}_{\mathrm{p}}$, because of the absence of a seasonal signal in this geological archive.

(2) On an inter-annual time scale, there is a weak inverse correlation between weighted average annual $\delta^{18} \mathrm{O}_{\mathrm{p}}$ and annual average temperature at Urumqi $(r=-0.28, n=11)$; and a stronger inverse correlation between weighted average warm season (May to September) $\delta^{18} \mathrm{O}_{\mathrm{p}}$ and warm season average temperature $(r=-0.44, n=11)$. In addition, the inverse trends of $\delta^{18} \mathrm{O}$ records in 4 ice cores and regional temperature in the central and eastern Tianshan Mountains during the past 40-50 years confirm the reality of an inverse correlation between $\delta^{18} \mathrm{O}_{\mathrm{p}}$ and temperature on an inter-annual time scale.

(3) On inter-annual or longer time scales in the Tianshan Mountains region, the variations of $\delta^{18} \mathrm{O}_{\mathrm{p}}$ are essentially caused by north-to-south shifts in the latitudinal position of the Westerlies 
The $\delta^{18} \mathrm{O}_{\mathrm{p}}$ values are more negative due to a larger proportion of long-distance water vapor transport from high-latitude sources region during warmer intervals when the Westerlies shifted to a more northerly location. When temperatures fall and the Westerlies shift to a more southerly location, the increased transport of water vapor from more proximal mid- to low-latitude sources leads to more positive $\delta^{18} \mathrm{O}_{\mathrm{p}}$ values. This 'Westerly circulation effect' is important for clarifying and explaining both paleoclimatic records such as stalagmite $\delta^{18} \mathrm{O}$ values and patterns of regional climatic change. Apparently, the relationships between $\delta^{18} \mathrm{O}_{\mathrm{p}}$ and climatic factors on inter-annual, inter-decadal and even longer time scales are much more valuable for the interpretation of associated proxy paleo-records. Therefore, more long-term observations of modern $\delta^{18} \mathrm{O}_{\mathrm{p}}$ are needed to better understand the climatic history of ACA and other regions. Finally, we suggest that improving our knowledge of the factors influencing relatively short-term variations in $\delta^{18} \mathrm{O}_{\mathrm{p}}$ may aid understanding of possible future climatic changes on longer time scales.

\section{Acknowlegement}

We sincerely thank Professor Hou Shugui, School of Geographic and Oceanographic Sciences, Nanjing University, for providing us with the ice core oxygen isotope data from No.1 glacier and Miaoergou glacier, and with the measured temperature data from Daxigou Meteorological Station. We highly appreciate Dr Jan Bloemendal for substantially improving the English.

\section{References}

Aizen V B, Aizen E M, Joswlak D R et al., 2006. Climatic and atmospheric circulation pattern variability from ice-core isotope/geochemistry records (Altai, Tien Shan and Tibet). Annals of Glaciology, 43: 49-60.

Chen F H, Chen J H, Holmes J et al., 2010. Moisture changes over the last millennium in arid Central Asia: A review, synthesis and comparison with monsoon region. Quaternary Science Reviews, 29(7/8): 1055-1068.

Chen Fahu, Chen Jianhui, Huang Wei, 2009. A discussion on the westerly-dominated climate model in mid-latitude Asia during the modern interglacial period. Earth Science Frontiers, 16(6): 23-32. (in Chinese)

Chen F H, Chen X M, Chen J H et al., 2014. Holocene vegetation history, precipitation changes and Indian Summer Monsoon evolution documented from sediments of Xingyun Lake, south-west China. Journal of Quaternary Science, 29(7): 661-674.

Chen F H, Wang J S, Jin L Y et al., 2009. Rapid warming in mid-latitude Central Asia for the past 100 years. Frontier of Earth Science in China, 3(1): 42-50.

Chen F H, Yu Z C, Yang M L et al., 2008. Holocene moisture evolution in arid Central Asia and its out-of-phase relationship with Asian monsoon history. Quaternary Science Reviews, 27(3/4): 351-364.

Chen J H, Chen F H, Feng S et al., 2015. Hydroclimatic changes in China and surrounding areas during the Medieval Climate Anomaly and Little Ice Age: Spatial patterns and possible mechanisms. Quaternary Science Reviews, 107: 98-111.

Cheng Hai, Edwards R L, Wang Xianfeng et al., 2005. Oxygen isotope records of the stalagmites from southern China. Quaternary Sciences, 25(2): 157-163. (in Chinese)

Cheng H, Zhang P Z, Spöt C et al., 2012. The climatic cyclicity in semiarid-arid central Asia over the past 500,000 years. Geophysical Research Letters, 39: L01705.

Dai Xingang, Li Weijing, Ma Zhuguo, 2006. The variation characteristics of water vapor source in Xinjiang in recent decades. Progress in Natural Science, 16(12): 1651-1656. (in Chinese)

Dai Xingang, Ren Yiyong, Chen Hongwu, 2007. Multi-scale feature of climate and climate shift in Xinjiang over the past 50 years. Acta Meteorologica Sinica, 65(6): 1003-1010. (in Chinese)

Dayem K E, Molnar P, Battisti D S et al., 2010. Lessons learned from oxygen isotopes in modern precipitation applied to interpretation of speleothem records of paleoclimate from eastern Asia. Earth and Planetary Science 
Letters, 295: 219-230.

Feng F, Li Z Q, Zhang M J et al., 2013. Deuterium and oxygen 18 in precipitation and atmospheric moisture in the upper Urumqi River Basin, eastern Tianshan Mountains. Environmental Earth Sciences, 68(4): 1199-1209.

Genty D, Labuhn I, Hoffmann G et al., 2014. Rainfall and cave water isotopic relationships in two South-France sites. Geochimica et Cosmochimica Acta, 131: 323-343.

Herzschuh U, 2006. Palaeo-moisture evolution in monsoonal Central Asia during the last 50,000 years. Quaternary Science Reviews, 25: 163-178.

Hong B, Gasse F, Uchida M et al., 2013. Increasing summer rainfall in arid eastern-Central Asia over the past 8500 years. Scientific Reports, 4(5279): 1-10.

Hou Shugui, Qin Dahe, Li Zhongqin et al., 1998. Present environment processes of ice core $\delta^{18} \mathrm{O}$ records of the No.1 glaciers at the headwater of Urumqi River, Xinjiang, China. Geochemica, 27(2): 108-116. (in Chinese)

Hou S G, Qin D H, Mayewski P A et al., 1999. Climatological significance of $\delta^{18} \mathrm{O}$ in precipitation and ice core: A case study at the head of the Urumqi River, Tien Shan, China. Journal of Glaciology, 45(151): 517-523.

Hou S G, Ren J W, Qin D H, 2006. Modification of three ice core $\delta^{18} \mathrm{O}$ records from area of high melt. Annals of Glaciology, 43: 172-176.

Huang W, Chen F H, Feng S et al., 2013. Interannual precipitation variations in the mid-latitude Asia and their association with large-scale atmospheric circulation. Chinese Science Bulletin, 58(32): 3962-3968.

Johnson K R, Ingram B L, 2004. Spatial and temporal variability in the stable isotope systematics of modern precipitation in China: Implications for paleoclimate reconstructions. Earth and Planetary Science Letters, 220: 365-377.

Krklec K, Domínguez-Villar D, 2014. Quantification of the impact of moisture source regions on the oxygen isotope composition of precipitation over Eagle Cave, central Spain. Geochimica et Cosmochimica Acta, 134: 39-54.

Leng M J, Marshall J D, 2004. Palaeoclimate interpretation of stable isotope data from lake sediment archives. Quaternary Science Reviews, 23: 811-831.

Li Hui, Zhou Hongfei, 2007. Variation characteristics of $\delta \mathrm{D}$ and $\delta^{18} \mathrm{O}$ stable isotopes in the precipitation of Urumqi. Journal of Arid Land Resources and Environment, 21(9): 46-50. (in Chinese)

Liu Rui, Yang Qing, 2010. Calculation and analysis of water vapor transportation and its net income in Xinjiang. Journal of Desert Research, 30(5): 1221-1228. (in Chinese)

Liu Zhongfang, Tian Lide, Yao Tandong, 2009. Spatial distribution of $\delta^{18} \mathrm{O}$ in precipitation over China. Chinese Science Bulletin, 54(6): 804-811. (in Chinese)

Long H, Shen J, Tsukamoto S et al., 2014. Dry early Holocene revealed by sand dune accumulation chronology in Bayanbulak Basin (Xinjiang, NW China). The Holocene, 24(5): 614-626.

Luo W J, Wang S J, 2008. Transmission of oxygen isotope signals of precipitation-soil water-drip water and its implications in Liangfeng Cave of Guizhou, China. Chinese Science Bulletin, 53(21): 3364-3370.

Marcott A S, Shakun J D, Clark P U et al., 2013. A reconstruction of regional and global temperature for the past 11,300 years. Science, 339: 1198-1201.

McCarroll D, Loader N J, 2004. Stable isotopes in tree rings. Quaternary Science Reviews, 23: 771-801.

Rao Z G, Liu X K, Hua H et al., 2014. Evolving history of the East Asian summer monsoon intensity during the MIS5: inconsistent records from Chinese stalagmites and loess deposits. Environmental Earth Sciences. doi: 10.1007/s12665-014-3681-z.

Rhodes T E, Gasse F, Lin R et al., 1996. A Late Pleistocene-Holocene lacustrine record from Lake Manas, Zunggar (northern Xinjiang, western China). Palaeogeography, Palaeoclimatology, Palaeoecology, 120(1/2): 105-121.

Shi Y F, Shen Y P, Kang E S et al., 2007. Recent and future climate change in Northwest China. Climatic Change, 80: 379-393.

Shi Yuguang, Sun Zhaobo, 2008. Climate characteristics of water vapor transportation and its variation over Xinjiang. Plateau Meteorology, 27(2): 310-319. (in Chinese)

Song Linlin, Hou Shugui, Liu Yaping, 2011. $\delta^{18} \mathrm{O}$ record of the Miaoergou ice core from the Karlik mountains of 
the east Tianshan since 1953. Journal of Lanzhou University (Natural Sciences), 47(5): 36-41. (in Chinese)

Tan Ming, 2011. Trade-wind driven inverse coupling between stalagmite $\delta^{18} \mathrm{O}$ from monsoon region of China and large scale temperature: Circulation effect on decadal to precessional time scales. Quaternary Sciences, 31(6): 1086-1097. (in Chinese)

Tan M, 2014. Circulation effect: Response of precipitation $\delta^{18} \mathrm{O}$ to the ENSO cycle in monsoon regions of China. Climate Dynamics, 42: 1067-1077.

Thompson L G, Yao T D, Davis M E et al., 1997. Tropical climate instability: The Last Glacial Cycle from a Qinghai-Tibetan ice core. Science, 276: 1821-1825.

Tian L D, Yao T D, MacClune K et al., 2007. Stable isotopic variations in west China: A consideration of moisture sources. Journal of Geophysical Research, 112: D10112.

Wang Jiao, Ren Yiyong, 2005. Study on the change of precipitation and general circulation in Xinjiang. Arid Zone Research, 22(3): 326-331. (in Chinese)

Wang W, Feng Z D, 2013. Holocene moisture evolution across the Mongolian Plateau and its surrounding areas: A synthesis of climatic records. Earth-Science Reviews, 122: 38-57.

Wang Xu, Ma Tie, Ma Yu, 2001. Characteristics of water vapour transfer in upper-middle Troposphere over Xinjiang. Xinjiang Meteorology, 24(2): 1-3. (in Chinese)

Wang Y J, Cheng H, Edwards R L et al., 2001. A high-resolution absolute-dated Late Pleistocene Monsoon Record from Hulu Cave, China. Science, 294: 2345-2348.

Wei Keqin, Lin Ruifen, 1994. The influence of the monsoon climate on the isotopic composition of precipitation in China. Geochemica, 23(1): 33-41. (in Chinese)

Yang Lianmei, 2003. Climate change of extreme precipitation in Xinjiang. Acta Geographica Sinica, 58(4): 577-583. (in Chinese)

Yang X L, Liu J B, Liang F Y et al., 2014. Holocene stalagmite $\delta^{18} \mathrm{O}$ records in the East Asian monsoon region and their correlation with those in the Indian monsoon region. The Holocene, 24(12): 1657-1664.

Yang X P, Scuderi L, Paillou P et al., 2011. Quaternary environmental changes in the drylands of China: A critical review. Quaternary Science Reviews, 30: 3219-3233.

Yao T D, Masson V, Jouzel J et al., 1999. Relationships between ${ }^{18} \mathrm{O}$ in precipitation and surface air temperature in the Urumqi River Basin, east Tianshan Mountains, China. Geophysical Research Letters, 26(23): 3473-3476.

Zhao Chuancheng, Wang Yan, Ding Yongjian et al., 2011. Spatial-temporal variations of temperature and precipitation in northern China in recent 50 years. Plateau Meteorology, 30 (2): 385-390. (in Chinese)

Zheng Shuhui, Hou Fagao, Ni Baoling, 1983. Hydrogen and oxygen isotopes compositions of atmospheric precipitation in China. Chinese Science Bulletin, 13: 801-806. (in Chinese) 